\title{
Swedish career guidance counsellors' recognition of newly arrived migrant students' knowledge and educational strategies
}

\author{
Fredrik Hertzberg ${ }^{1^{*}}$ \\ ${ }^{1}$ Stockholm University
}

\section{Abstract:}

This article studies the recognition of newly arrived students (NAS) knowledge in Swedish career guidance. It aims to analyze how career guidance (CG) counsellors at public schools a) describe and assess the already existing knowledge and competences of NAS, and b) express opinions towards their viewpoints on learning, education and work. The article is based on a qualitative analysis of semi-structured interviews with five CG counsellors. The notion of "recognition" denote both the evaluation of a) knowledge and $b$ ) the general attitudes towards educational choosing. The acts of evaluation studied are informal in character, and derive from interviews with CG counsellors. The knowledge of NAS about the labor market and the educational system are considered inadequate, and that their vocational aspirations were held to be erratic, narrow and rigid. Educational preferences and strategies influenced by a collectivistic ethos are regarded as pedagogically and ethically erroneous, and are not recognized.

Keywords: Newly arrived migrants, career guidance counselling, vocational and educational guidance, recognition, knowledge.

\footnotetext{
* Principal contact:

Fredrik Hertzberg

Department of Education, Stockholm University, Sweden

E-mail: fredrik.hertzberg@edu.su.se
}

Peer Reviewed Article. Published: 15.05.2017

Nordisk tidsskrift i veiledningspedagogikk 2017 (C2017 Fredrik Hertzberg

This is an Open Access article distributed under the terms of the Creative Commons Attribution 4.0 International License (CC-BY, http://creativecommons.org/licenses/by/4.0/)

DOI: http://dx.doi.org/10.15845/ntvp.v2i1.1220 


\section{Introduction}

The aim of this article is to study the recognition of newly arrived migrant students' (NAS) knowledge in Swedish career guidance (CG), or, to be more precise, to analyze how CG counsellors at public schools a) describe and assess the already existing knowledge and competences of NAS, and b) describe and express opinions towards NAS' attitudes about and viewpoints on learning, education and work. My research questions are: do the counsellors recognize the knowledge and the different perspectives on work-life and education that NAS express, or not? If so, why? And which are the implications of such a lack of recognition, if any?

The notion of "recognition" is here held to denote the informal assessment of a) knowledge and b) the general attitudes towards educational choosing. I will refer to recognition in a a) "thin" and b) "thick" sense, respectively; the former term denotes the recognition of relatively delimited instances of knowledge, while the latter denotes broader chunks of meaning-making. As mentioned, the acts of evaluation studied in this article are informal in character, and derive from interviews with career counsellors at public primary schools. The article is based on semi-structured interviews with five CG counsellors, and the data collected is subject to a qualitative analysis. The NAS referred to during the course of interviews were mainly refugees from Syria, Eritrea, Somalia and Afghanistan. The study of CG practice and practitioners is relevant and fruitful for the understanding of processes of recognition, as the respect for and attention to the already existing knowledge of the counselee is inscribed in the professional ethos and influential theoretical models for CG. In Sweden, this tendency is apparent, and in the next section, a brief history of career counselling in Swedish public schools will be outlined, in order to point out the tenets of this tendency.

\section{Career guidance in Swedish schools}

Public career guidance for youth came into being in the 1940s. Back then, CG services were considered a key feature for the promotion of full employment. Matching between young people's vocational choices and the needs of the labor market was held to be of greatest importance, not only because the Swedish labor market was characterized by stable economic growth and shortage of manpower, but also because of the ambition to bring about economic restructuring and employment growth through industrial adjustment. In the late 1960 s and early 1970 s, the promotion of social justice became more emphasized in educational policy. CG was expected to compensate for social and gender-related obstacles to the career choosing process and provide a counterweight to influences that could limit or bias young people's choices (Lundahl \& Nilsson, 2009). This progressive project underscored the interest of the individual, which gained precedence over labor market interests.

With the introduction of a university college program in study and career counselling in the early 1990s, the focus on the interests of the individual became even stronger in Swedish CG counselling practice. Constructivist theories of career counselling methodology (Savickas, 1993; Peavy, 1996) and the humanistic pedagogy of Carl Rogers' (1951) client-centered therapy exerted great influence in this program (Lovén, 2003), and the effect was apparent: in the shaping of a professional ethos at the university, the task of matching the labour market supply and demand was subordinated to matters of personal development and the individual construction of meaning. The implication for the pursuit of recognition is evident: attention to and respect for the self-image, world-views and values of the counselee became imperatives and regarded as central for the progression of the learning process.

When it comes to NAS in Sweden, they receive CG on the same terms as other students. The quantity and the quality of the services are dependent upon local routines, regulations, and 
allocation of resources. CG in lower secondary education, which is the focus of this article, is primarily engaged with the task of choosing upper secondary education. For NAS, a number of alternatives are at hand in the Swedish educational system. First of all, there is the option to choose so-called national programs, i.e. regular programs at upper secondary schools. These are either preparatory or vocationally-oriented. NAS who do not meet the standards of eligibility are generally recommended to apply for the language introduction program (sw. språkintroduktion).

There are a number of normative texts on counselling in general which promotes the pursuit of recognition (e.g. Palmer \& Laungani, 1999; Ponterotto et al., 2001; Sue \& Sue, 2001). When it comes to CG counselling, the selection of advocate texts are narrower, but still manifold (e.g. Peavy, 1996; Launikari \& Puukari, 2005; Arulmani et al., 2014; Yakushko et al., 2015). The empirical study of the actual conditions for recognition in CG is not that extensive, however, but a limited number of studies are found. For example, studies on CG of ethnic minorities in Sweden (Sawyer, 2006) and elsewhere (Yogev \& Roditi, 1987; Resh \& Erhard, 2002) suggest that migrant and/or ethnic minority students may be subjected to the "cooling out" of their career aspirations. Implicit or explicit calls for "realism" in CG, predicated on low (and unfair) expectations of migrant and/or minority students, result in revised and downgraded career aspirations and educational strategies.

In a recent Swedish study, Sundelin (2015) also notes that certain features in the practice of CG brought about a neglect of transnational relations and opportunities, an inattention to prior knowledge, and a partial lack of understanding for the overall refugee predicament and the fear of discrimination (Sundelin, 2015, ch.13). It could reasonably be said that those features hampered the pursuit of recognition. Still, there are also studies which claim that the everyday local practice of CG in Swedish schools is influenced by an egalitarian ethos, which promotes social inclusion and integration on rather equal terms (Hertzberg, 2015). This suggests that the absence of recognition in Swedish CG may come out as an unintended by-product, rather as the result of a programmatic, assimilatory ambition.

\section{Newly arrived students in Sweden}

The total number of asylum seeking children in Sweden in 2012 was 14.000, in 2013 16.000, in 2014 23.000 and in 2015 just above 70.000 (Migrationsverket, 2017). Apart from the category of asylum seekers, we also find children who arrive for family reunion, children of labour migrants, and undocumented refugee children. A NAS is defined as "a student who has migrated regardless of reason, who do not possess basic knowledge in the Swedish language, and enters elementary (or upper secondary) education just prior to or during the regular academic year" (Nilsson \& Bunar, 2016, p.402). The major institutional response to this category of children has been to appoint their legal status, rather than considering them as children in need of education (Nilsson \& Bunar, 2016).

Recent research claims that the discussions concerning pedagogical needs of newly arrived youth are generally devoted to second language (i.e. Swedish) acquisition, and this holds true for the exchange of meaning in several arenas: public discourse (Bunar, 2010), educational policy (Borevi 2002; Ljungberg 2005) and research (Bunar, 2010). In educational policy, the tuition of Swedish is often presented as the major pedagogical response towards newly arrived students (cf. Ds 2013, p.6). What the newly arrived students already know is seldom at the center of attention.

At the level of pedagogical practice at school, parallel tendencies are discernible. The assignment of NAS to different forms of education mainly follows already established (local) institutional practices rather than from estimates of their individual pedagogical needs (Nilsson \& Bunar,2016). Moreover, they are not provided with adequate bilingual learning support. The task of providing these didactical devices, which are held to be central to the task of learning Swedish as 
second language (Axelsson, 2015; Kaya,2016, cf. Cummings,1991), is quite often overlooked. In addition, several qualitative studies (e.g. Parszyk, 1999; Runfors, 2003; Gruber, 2007) that analyze everyday teaching practices at schools have found that students categorized as "immigrants" (sw. invandrare) are regularly described as problematic, mainly due to their lack of proficiency in Swedish, but also due to their attention to culturally derived norms and values held to be alien to the dominant Swedish standards

However, the importance of mapping the knowledge of NAS has been acknowledged and pointed out in educational policy (Skolverket 2008/2013), and a number of counties and municipalities have also issued regional or local guidelines for the accomplishment of these mapping tasks. But a newly issued inventory of the mapping competencies at the local school level (Skolverket, 2014) identifies a strong need for professional development in these matters. In conclusion: the task of mapping the knowledge of NAS has gained attention, but there are several observations from inspections and research, which suggest that a) there is a strong tendency in the Swedish school system to focus only on NAS need for further education and second language acquisition, and $b$ ) there is a correspondent lack of attention to the already existing knowledges and competencies among NAS. What they already know is underrated and misrecognized, rather than recognized. These results provide the starting point for this article, and motivate its aim and focus.

\section{The recognition of knowledge, norms and values}

When it comes to the inclusion of migrants, most recipient countries have organized practices which regulate their admission into the educational system and labor market. The recognition of their skills is one of the central tasks of these practices. In Anglophone countries, and some others, these mapping, validating och recognizing practices for adults are often labelled as RPL (recognition of prior learning; cf. Andersson \& Harris, 2006) or PLAR (prior learning assessment and recognition prior learning; Spencer, 2005). Research on these practices has had a rather practical focus, e.g. analyzing different attempts to realize and implement recognizing practices around the world, and the extent of theoretical research has been rather limited (Andersson, Fejes \& Sandberg, 2013).

RPL and PLAR practices are generally employed in order to evaluate skills and knowledge (learning) acquired outside the classroom for the purpose of recognizing competence against a given set of standards or learning outcomes. These skills and competencies are something else than the matters discussed here, i.e. knowledge on educational institutions and labor market, and attitudes towards education, work and future among (refugee) youth in primary education. While the focus of RPL and PLAR practices are practical in character, the skills and competencies discussed in this article are mainly non-practical and factual; to a certain degree, it is a matter of meaning-making unrelated to individual agency and experience, such as notions of future prospects.

The literature on RPL, PLAR and similar activities are thus less relevant here, but there are a number of studies whose argument runs parallel with ours. For example, several studies show how procedures for assessment and evaluation of migrants' prior learning conduce misrecognition of their skills (Webb 2015), or, even worse, their overall social exclusion (Andersson \& Osman, 2008; Diedrich \& Styhre, 2013; Vesterberg, 2015). Attention to the misrecognition of migrant knowledge acquired outside the country of reception is a recurring theme here. This is a reminder of the fact that what is counted as skill and competency, and who are considered to be skilled and competent individuals, are actively shaped by an interplay of social, cultural and economic relations (Shan \& Fejes, 2015). In this perspective, recognition (or, rather, misrecognition) may be a matter of boundary maintenance.

The term recognition is polyvalent, and a number of interpretations have been put forth in philosophy, pedagogy and social science (cf. Taylor 1994; Honneth, 1997; McQueen, 2015). Two 
different but interrelated aspects of recognition will be analyzed here. Firstly, and in line with the literature on RPL and PLAR, recognition refers to the counting of something as a skill, a competence or knowledge. This is a rather "thin" definition, in which the mere act of approval is central. In order to recognize the skills and competences of $B, A$ accordingly identifies $B$ as a competent and skillful person.

Secondly, and in line with Taylor (1994), recognition also refers to the act of identifying the uniqueness, i.e. the peculiar and the specific, of each individual or group. Taylor's emphasis on the unique is relevant in the context of political philosophy, where recognition is a part of the "politics of difference", which claims that the recognition of the world-views, truth-claims and ethos of minority groups secure their standing as full citizens in a given society. Nonrecognition or misrecognition in these matters can "be a form of oppression, imprisoning someone in a false, distorted, and reduced mode of being" (Taylor 1994, p.25), since recognition has profound importance on the formation of social identity, and the ways in which people understand who they are and their fundamental characteristics as human beings (McQueen, 2017). Here, recognition targets the practice of meaningmaking: norms, values, ideas and propositions constitute the subject matter that is to be recognized. Compared to the "thin" definition of recognition outlined above, this definition is rather "thick" when it comes to the size of the target of recognition. As noted above, these two definitions will both be employed in this article.

There are also some implications for matters of learning inherent in the notion of recognition. In the socio-cultural pedagogy of Vygotsky (1978), where learning is perceived as a process of collaboration between learners, it is implicated that the guiding adult/authority needs a specific understanding of what the learner already knows (i.e. the starting point of the development process) and what $s /$ he is about to learn (i.e. the end goal of the present activity). $S /$ he needs a tentative understanding of the "starting point" of the learning process - from where do we begin? What is the learner capable of doing with some guiding assistance? Accordingly, among the instructions for the teacher/the authority, we find a request to listen to the students, observe them, and try to understand where they are located in their travel towards knowing, in order to design the appropriate instructing devices and tasks. This request for understanding could be understood as an aspect of recognition, and is also held to be important in the teaching of NAS (Cummings, 2000). Thus, there are some implications for the question of learning found here, and they will briefly be commented upon.

\section{Method}

\section{Project description}

The empirical material presented here was produced in a cross-disciplinary qualitative research project, which studied the learning conditions for NAS in Swedish schools. The study was carried out at schools in three different municipalities: one in a metropolitan area, one in a middle-sized town and one in a small provincial town in a rural area. Several categories of professionals and stakeholders, such as students, teachers, CG counsellors, principals, minor and senior officials and local politicians, were approached. The interviewees voluntarily accepted taking part in the project, and were - in accordance with the rules of the funding body - informed on the terms of participation (i.e. informed consent).

The subproject focusing on career guidance was a minor study. Its general aim was twofold. Firstly, it aimed to study the professional challenges that CG counsellors meet in the process of counselling newly arrived migrants, as well as the pedagogical solutions and deliberations that 
followed from these challenges. Secondly, it aimed to study the discursive and organizational context in which the counselling activities were embedded, such as general objectives, management, and the allotment of human and fiscal resources. The aim of this article is derived from the first one. The study employed a qualitative method, viz. semi-structured in-depth interviews. 15 CG counsellors or stakeholders in CG were interviewed, of which four career counsellors are quoted here. The number of interviewees is relatively small, which might endanger the external validity (LeCompte \& Goetz, 1982) of the study, and it could be questioned whether the state of "data saturation" (Glaser \& Strauss, 1967) is reached, i.e. if no additional data that develop aspects of the conceptual categories could be found. Although the interpretations and the standpoints explicated by our interviewees derive from a professional experience comprised of meetings with several hundred NAS, this remains an important criticism of the method employed here.

\section{The sites and the interviewees}

In the metropolitan school, the number of NAS was close to 20 and the percentage of students with a migrant background was close to 100 , which means that nearly all students were multilingual and the staff was familiar with the predicament of migrant students. The catchment area is relatively poor, and the vast majority of the inhabitants was born outside Sweden; thus, it makes sense to say that the NAS were integrated in school, but segregated geographically and socially when it came to housing and living. In the small-town school, the number of NAS was 10 , and $3 \%$ of the school population was multilingual and spoke Swedish as a second language. Most of the teachers at the school lacked wide professional experience in teaching migrant students. In the medium-sized town, the number of NAS was 52 , and $30 \%$ of the total school population was multilingual. The geographical segregation was apparent in the small- and medium-sized towns, but not as obvious as in the metropolitan area. However, the social segregation was quite manifest in these schools.

The CG counsellor in the metropolitan school (cf. above) was a man in his late 40s. In the midsized town, two CG counsellors at two different schools were interviewed. The first one was a young woman in her late 20s, and the second was a woman in her late 40s. In the small-town school, the interviewee was a woman in her early $60 \mathrm{~s}$. They were all trained in the university college program in CG. The professional CG career of the older interviewees had a time span of 15 to 20 years, and the youngest one had been practicing for almost five years. All of them counselled NAS, although most of their time was allotted to the guidance of other students.

\section{Notes on the analysis of qualitative data}

The methodology of this article conjoins with the general guidelines and commitments of qualitative methodology and aims at a qualitative content analysis (Graneheim \& Lundman, 2003). Being a qualitative study, it aims at an understanding of the ways in which several view-points, attitudes and practices are interrelated, and the ways in which these expressions are compatible with a specific ethical stance (i.e. the thick understanding of recognition). The hermeneutics employed in this article is of both faith and suspicion (Ricoeur, 1981). It strives to combine the acknowledgement of agency, intentionality, subjectivity and meaning-making with the pursuit of uncovering meanings which transcends the consciousness of the social actor, e.g. misrecognition as an unintended by-product of certain pedagogies.

The qualitative data collected and analyzed here are made up by the interviewees' answers to questions regarding the pedagogical needs of NAS and the didactical practices that are held to respond to those needs. These chunks of data are regarded as meaning units, which has been grouped together under higher order headings to facilitate interpretation. Three broad categories of data were singled out: 1 ) what do the counsellors say about the knowledge of NAS, 2) what do the 
counsellors say about the ways in which NAS manage educational and vocational choosing, and 3) how do the counsellors describe the ways in which they work with NAS, and - in particular - what pedagogical interventions are designed in order to meet their specific needs.

The order of headings found in the results section roughly corresponds to the these broad categories: 1) "CG counsellors viewpoints on the NAS' knowledge of working life and the Swedish educational system"; 2) "CG counsellors' viewpoints on the NAS' vocational aspirations and educational strategies", and 3) "The didactic interventions of the CG counsellors". The quotations from the interviews presented in the text represent the "most frequent standpoint" found in the interviews. In case of an apparent plurality of meaning, such as clearly divergent opinions or interpretations, major deviations from the "most frequent standpoint" are included in the line of argument.

\title{
Results and some preliminary discussions
}

\section{Career guidance counsellors' viewpoints on the newly arrived students' knowledge of working life and the Swedish educational system}

By way of introduction, I will describe the ways in which CG counsellors represented the newly arrived students' knowledge of working life. The excerpts below were given as answers to questions regarding the needs of NAS, and the learning activities held to meet these needs. The counsellor in the metropolitan area school put it this way.

\footnotetext{
Interviewee (I): "I mean, seriously, their knowledge about how society functions is close to zero. It is really that bad. When it comes to knowledge about the requirements for being a bus driver or an architect or a cleaner, I really don't know why, but it is lacking. /.../ Some of them, from some parts of the world, they seems to think that 'I can do it, I can get it'. But here, instructions or training is needed, in order to something. And I dare say that $90 \%$ of our students, and their parents, lack knowledge in this matter."
}

The older counsellor from the mid-sized town highlighted a slightly different aspect:

\begin{abstract}
I: "There are so many words that they don't recognize, and then you have to explain what it takes to be an engineer, for example. I was thinking about a girl that I met, she wanted to be an engineer, and I had to tell her exactly what an engineer does. And you have to explain that for her, and at the same time she doesn't know at all how to get there."
\end{abstract}

These excerpts highlight the alleged absence of knowledge on the content of certain vocations and the ways in which the qualifications and requirements for certain vocations are fashioned. According to the interviewees, they do not really know what an engineer (or an architect, or an assembler) does. Some of them claim that only a limited number of vocations, such as doctor, lawyer, pharmacist or mechanic, are known in this regard, and they explain this scarcity with reference to the labor market conditions in their native country. Two remarks can be made about these alleged gaps. Firstly, it was held that they were quite extensive. Secondly, it was also implied - and sometimes explicated, cf. above - that the existence of these gaps of knowledge was obvious and explainable. The gaps concerned knowledge on the peculiarities of the Swedish labor market, of which NAS from other parts of the world had more or less no possibility to acquire yet. Here, the absence of recognition was not connected to the misrecognition of meaning-making. 
The remarks above are also valid for the second category of alleged gaps of knowledge - the lack of knowledge about the Swedish educational system. The counsellor from the small town elaborated on this matter when she described the content of the counselling sessions with NAS and their parents.

I: "Well, you just have to do it; you have to explain how the school system looks like, in every detail, for the students and for the parents. [You have to explain] the transition from school to work, when it comes to primary school and secondary school, and what there is to do afterwards. You have to talk a lot about it when you meet."

Obviously, these gaps are held to be extensive, and considerable efforts are necessary to overcome them. The counsellor in the Metropolitan school held a similar view:

I: "And then there are another set of problems, and that concerns the function of the educational system. /.../ You have to do some work there, really ... incredibly much work. About the educational system, about the school as such; the most basic stuff. /.../ By and large, it is a matter of ignorance."

According to this interviewee, the gap is not only wide, but also deep; information on the "most basic stuff" is necessary. The knowledge of newly arrived students is seen as insufficient and inadequate, and it is held that the alleged gaps of knowledge may be detrimental to the counselling process. Thus, the final remarks under the last header are even more valid here. The alleged gaps were not presented as odd or challenging, but rather as something that follows from the predicament of being a NAS. Still, we find a quite straight-forward critical approach towards NAS' knowledge of vocations and working life requirements ("their knowledge ... is close to zero", "you have to do some work there, really") - and the sharpness bring some questions to the fore. To what degree does their emphatic judgement also cover matters such as values and attitudes, i.e. the "web of meaning" in which the knowledge of NAS is embedded? Do the CG counsellors also hold a certain disinterest or indifference towards conceptions and notions related to the realm of work, which are developed in the NAS' native countries?

If the latter is true, we may also witness a lack of recognition in the thick sense: the counsellor/authority does not pay attention to the point from which the process of learning starts, i.e. the "web of meaning" referred to above. This is a critical question, since such inattention, or lack of recognition, may hamper the process of learning if we give credence to the didactical predictions of Lev Vygotsky (1978). In the following section, I will describe and analyze the attitudes of the CG counsellors towards the vocational aspirations and educational strategies of NAS - aspirations and strategies which are a part of the web of meaning referred to above.

\section{Career guidance counsellors' viewpoints on the newly arrived students' vocational aspirations and educational strategies}

In the analytical perspective employed here, vocational aspirations and educational strategies are seen as related to matters of knowledge and learning. Vocational aspirations do not only single out what is considered to be interesting and/or profitable enough as a future activity and means of livelihood, or determine what kinds of work fit and strengthen my social identity. They also imply which kind of learning processes and educational efforts seem meaningful, tolerable and worthwhile. In a similar way, educational strategies express or imply notions of meaningful educational targets, desirable future competencies and/or other outputs, as well as prospective social identities. 
Accordingly, approvals or disapprovals of other people's vocational aspirations and educational strategies might be seen as an approval or disapproval of their attitudes towards knowledge and learning.

The counsellors had a number of objections to some of the vocational aspirations and educational strategies found among NAS. The objections were related to one of the central learning outcomes of CG, viz. the ability to choose among certain alternatives in an independent and responsible way (Hertzberg, 2015). The aspirations of NAS were held to be narrow and rigid. For example, the counsellor of the Metropolitan school had some worries about the vocational aspirations implied in the notions of the future expressed by his students.

I: "If I walk into a class and ask them, "just pretend that we set the clock forward ten years, what do you do?' I can assure you, $70 \%$ tells you that they are a doctor. Yes. And $20 \%$ will tell you that they have become a lawyer. And then one engineer here or there.

The younger counsellor from the mid-size town expressed a similar viewpoint.

I: "According to my experience, those [newly arrived] foreign born, there is no more than four vocations that come out [when asked for], and they are all related to the Natural science program; doctor, lawyer, engineer, maybe and then pharmacist, and it is like that among most of them. [...] Yes, it is very much directed towards those vocations, and I might imagine that in their native countries, those are the ones that count, that are visible, that are acknowledged status."

Related to the question of rigid aspirations are the interviewees' notions of how these aspirations were determined. It was claimed that the vocational aspirations of NAS are shaped not only by the students themselves but also by their parents - in an erratic way: the parents interfere in the counselling process, and the children are over-attentive to their demands. The older counsellor from the mid-size town expressed this view.

I: "[The NAS], they got it from home; they should become a doctor or some of these ... nice vocations, so it could be really hard during the counselling sessions. Really, really hard. They might be directed from home, like ... it is determined beforehand what they shall do. I haven't talked that much with their parents, but it is one of those things that are not too easy, they could be so incredibly focused and determined, and then it is quite hard to have a discussion on these topics. It is like ... it's the parents who settle things up."

The counsellors objected not only to the fact that parents influence their children but also that they interfere during the formation of vocational aspirations. Thus, the line that separates (legitimate) support from (illegitimate) influence has been crossed (Sawyer, 2006), and the vocational aspirations and educational strategies among NAS were held to be too narrow, rigid, and dependent on the volition of the parents. As will be discussed in the next section, it could be claimed that these judgments reflect a lack of recognition, and that the aspirations and strategies of NAS challenge the individualist outlook dominant in mainstream Swedish society.

The fact that aspirations towards high status vocations among migrant students are held to be erratic resonates with earlier research on career counselling of ethnic minorities in Sweden (Sawyer, 2006) and elsewhere (Yogev \& Roditi, 1987; Resh \& Erhard, 2002). As noted by way of introduction, these studies suggest that migrant and/or ethnic minority students are rather often subjected to the 
"cooling out" of their career aspirations, and that revised and downgraded career aspirations and educational strategies come out of the CG counselling sessions. It must be noted, however, that my interviewees recurrently pointed out that they did not object to the height of the aspirations, but to their rigidity. They wanted the students to widen and expand their plans. This didactic idea, and its implications, will be described below.

\section{The didactic interventions of the counsellors}

As implicated above, learning activities aimed at the building of knowledge on working life, the labor market and the educational system held a prioritized position on the CG agenda of our interviewees. Educational visits, work experience programs and visits at fairs were examples of external activities related to these learning outcomes. In order to construct knowledge on working life, the labor market and the educational system, they also organized group activities, seminars and presentations in class, and it was a top priority during the individual counselling session. Above all, the provision of information concerning the admissions requirements for upper secondary schooling was considered to be of uttermost importance.

Still, the pedagogical activities of the interviewees aimed not only at producing knowledge on what is going on in the world of educational systems and labor markets, but also knowledge of what is going on at the intrapersonal level. This pursuit was primarily focused on the identification of interests and desires, the widening of career plans and the ability to choose independently between a numbers of alternatives. The older counsellor from the mid-sized town described her practice as follows:

Fredrik: "But if we go back to the content of the counselling session, and what you said before [...] if you become aware of that ... this is not only the student's conceptions of the right way, but very much the conceptions of the parents. If you should guide them, in this context, what do you do?"

I: "Well, yes, in the counselling conversation, of course, first I try to get away from them [the parents], and get off in some way, and try to find it, the inner picture of whatever there is, but it so hard to reach it, because they are so ... well, this is what it is like. It has become the truth for them as well. And it is really hard to get away from it. But, absolutely, you could do that, and sometimes it happens, and then you notice that conflicts will occur."

The younger counsellor from the same town held a similar viewpoint:

I: "They bring their own norms and rules along, and I have preconceived opinions as well, unfortunately. But if a student brings along these norms and values, but then they break away from them, and manifest a will of their own, it is wonderful. But these processes are going on, and when I meet them in class, I dig a bit deeper in this matter, in order to make them conscious about it. [...]"

Fredrik: "And you say, in the end they have to choose for themselves, and no one else?" I: "Yes, because this is not self-evident for many foreign-born."

We can see that the interviewees object to the influence of parents in the forming of vocational aspirations, and to the adherence to certain norms and values. We can also see that an end goal for the pedagogical process is outlined: the finding of "an inner picture" and/or manifestations of their own volition. The didactical intervention thus resembles the pursuit of "digging a bit deeper".

Taking all the interviews into account, it could be said that the didactical intervention in this matter had two stages. Firstly, the students were requested to identify themselves as individuals 
with interests, preferences and volitions, which must be acknowledged and clarified. Secondly, they had to acknowledge that these interests, preferences and volitions should determine their educational and vocational choosing. The counsellors sought to infuse a specific attitude among their students, allegedly productive for the task of choosing an education or vocation. They also pointed out some specific competencies central for the enactment of the same task. These desired outcomes concerned the fostering of autonomy. A certain form of agency was requested, where dreams and personal inclinations should be taken seriously, goals should be pictured, and individual freedom and future possibilities should be recognized. At the core of this tendency, we find an emphasis on individual responsibility and deliberation.

Thus, the tendency described in the section above is confirmed. The act of choosing and the elaboration of educational strategies and vocational strategies are seen as fundamentally individual tasks, and collective rationalities are called in question. If students affirm the wishes of significant others, it is regarded as a partly erroneous attitude. The ideal from which NAS' strategies and aspirations is held to diverge, viz. the ideal of autonomy, holds a central position in the discourse of the interviewees. Their learning activities and didactical interventions lead up to this goal. As noticed above, this practice levels with the ideals and desired learning outcomes outlined in the present steering documents, e.g. the curriculum for the compulsory school (Skolverket, 2011).

The fact that several educational strategies and vocational aspirations are dismissed from the pursuit of autonomy manifests a paradox. The learning activities of the counsellors' aim at the freedom of choice, but certain ways of choosing are rejected in the name of this freedom: you are not free to follow the inclination of your parents. Hence, the emphasis placed on well-informed and independent choosing restricts the freedom of choice. This paradox reveals the existence of competing and conflicting interpretations of the concept "freedom of choice".

The pursuit of autonomy may also interfere with the politics of recognition. The acceptance of parental influence over the act of choosing and the striving for a child-parental consensus in matters of educational and vocational choosing is not only an obstacle for the pedagogical pursuit of autonomy. It may also be understood as a manifestation of collective decision-making within the realm of the (extended) family, and as an instance of an ethos of collectivity - a way of thinking that expresses a logic in its own right, and a strategy that tries to maximize the probability of reaching certain ends. ${ }^{1}$ If these proposals are held to be the true, it may be concluded that the pursuit of autonomy interferes with the ethics of recognition, as articulated by Taylor (1994) and others. In the guidance practices of our interviewees, the ethos of collectivity is treated as deviation from normality, rather than a frame of interpretation in its own right.

The explicit recognition of NAS knowledge was quite rare in our material. Although the issue of recognition seldom was explicated, the interviewees sometimes demarcated the limit for the promotion of autonomy and independent choosing. For example, one of the counsellors in the midsized town pointed out that she did not want to question deep-seated values concerning the relation between gender and appropriate vocation, although they might interfere in the widening of perspectives, which is a central in current counselling didactics. In order not to bring about personal trouble for the student, she sometimes "stepped back" in her ambition to encourage and strengthen individual volition disconnected from the values of the parental generation. In this way, the values

\footnotetext{
${ }^{1}$ Moreover, it might also be understood as a strategy that young people may prefer given the stress that follows from forced relocation and migration - but this is matter that will not be discussed here; cf. Yakushko et al, 2008.
} 
and ideas of the students were recognized, although the act of recognition came in through the back door.

\section{Conclusions and some questions for discussion and further research}

The aim of this article has been to study the recognition of migrant knowledge in Swedish career guidance, or, to be more precise, to describe and analyze whether or not career counsellors at public schools recognize a) the already existing knowledge and competences of newly arrived migrants, and b) their attitudes towards and viewpoints on learning, education and work. It is found that the knowledge of NAS about the labor market, above all the entry to and content of certain vocations, was considered inadequate. Certain gaps of knowledge were identified by the counsellors, and they were held to be extensive, but their existence was considered fully explainable, as they concerned knowledge on the peculiarities of a national labor market of which a NAS from another part of the world yet had no possibility to acquire. The same conclusion applies regarding the recognition of NAS knowledge on educational alternatives.

It might be concluded that these opinions and judgements express an absence of recognition in a "thin" sense, but not in a "thick" sense. Still, the straightforward and negative wording of the interviewees in this matter give cause for certain attention, and some questions arise. Does the sharp and critical attitude come off the matters of factual knowledge and on to the context of general production of meaning, above all values, norms and conceptions related to the realm of work-life and education? Is there a certain disinterest or indifference to conceptions and notions developed in the NAS' native countries? This study cannot deliver the answers to these questions, which is a shortcoming, but they are nevertheless important, given the theoretical frame of the article. An extended negative attitude is at the odds with the quest for recognition as developed by Charles Taylor (1994), and constitutes an obstacle for the process of learning, if the latter is described in line with the pedagogy of Vygotsky (1978, cf. Cummings, 2000).

The counsellors' viewpoints on the vocational aspirations and educational strategies of NAS were also studied. It was held that the vocational aspirations of NAS, as well as the concomitant educational strategies and choices, were sometimes erratic and too narrow and rigid. It was also held that these aspirations and strategies were shaped not only by the students themselves, but also by their parents. When the vocational aspirations of the NAS were aligned to the wishes of significant others, they were regarded as an erroneous, and a number of didactic interventions were designed to alter them. These learning activities aimed at the promotion of autonomy, which included a) the disposition to identify oneself as an individual with interests, preferences and volitions, which must be acknowledged and clarified, and b) the inclination to acknowledge that these interests, preferences and volitions should determine their educational and vocational choosing (Hertzberg, 2015).

The lack of recognition is more readily detected in this matter. The pedagogical enterprise aimed at the inculcation of autonomy conflicts with collective rationality and decision-making. Any set of values and norms that is characterized or influenced by a collectivistic ethos could be regarded as pedagogically and ethically erroneous. These aspirations stand out as a flawed rather than an object of recognition. Here, the limits of the multiculturalist "politics of difference" (Taylor, 1994) is pointed out - without any explicit reference to culture or ethnicity, only to pedagogical considerations. However, it was held that the promotion of autonomy might be abandoned if it seemed to irritate the relation between student and parent. Thus, the pursuit of recognition is not completely ruled out. 
The limitations of this study are first of all related to its limited empirical extent. The number of interviewees is relatively small, which might jeopardize the external validity of the study. In order to deal with his, I present proposals rather than conclusions. Two other limitations must also be acknowledged. Firstly, the study of the production of meaning in topics related to the recognition of non-western knowledge in Swedish CG is far from completed here. Only a small number of questions in this matter are addressed. Secondly, the article does not properly address the connection between the above-mentioned straight, critical-forward approach towards NAS' knowledge on vocations and working-life, and the interviewees' general attitudes towards non-western attitudes and conceptions of work, education and working-life. Hence, the eventuality of a general (mis)recognition of nonwestern indigenous models of career development (Leong \& Pearce, 2014) is not fully scrutinized, and it could accordingly be questioned whether the standard of "data saturation" (Glaser \& Strauss, 1967 ) is met or not. Therefore, a closer attention to CG counsellors' approach towards non-western work ethics and models of career development remain an important suggestion for future research.

Notwithstanding its shortcomings, this study brings some suggestions to the fore, when it comes to development of CG and the project of recognition. In order to help the latter to survive and proliferate, some rethinking is required. Above all, the conception of "freedom of choice" in the context of educational and vocational choosing must be expanded. The relatively narrow conception inherent in the idea of autonomy outlined above postulates that influences from significant others are undesirable, as are collective decision-making and rationalities. Thus, it could be claimed that the relevance of collective rationalities must be recognized. This holds true not only for politicalphilosophical reasons (Taylor, 1994), but also for didactical (Vygotsky, 1978): the disposition to embrace and accommodate the learning outcome of "autonomy" (here: well-informed, independent choosing) might more easily come about, if the concept includes voluntary acceptance of parental influence. Such a concept of autonomy in CG would more likely stand out as meaningful to the entire population of students, and reflect its diversity. These remarks remain the most palpable implication for policy found in this article. 


\section{References}

Andersson, P. \& Harris, J. (2006). Re-theorizing the recognition of prior learning. Leicester: NIACE.

Andersson, P. \& Osman, A. (2008). Recognition of Prior Learning as a Practice for Differential Inclusion and Exclusion of Immigrants in Sweden, Adult Education Quarterly, 59 (1), 42-60. DOI: $\underline{10.1177 / 0741713608325173}$.

Andersson, P., Fejes A. \& Sandberg, F. (2013). Introducing research on recognition of prior learning, International Journal of Lifelong Education, 32(4), 405-411. DOI: $\underline{10.1080 / 02601370.2013 .778068}$

Arulmani, G., Bakshi, A.J., Leong, F.T.J. \& Watts, A.G. (Eds,) (2014). Handbook of Career Development. International Perspectives. New York: Springer.

Axelsson, M. (2015). Nyanländas möte med skolans ämnen i ett språkdidaktiskt perspektiv [Newly arrived and teaching subjects in a language-didactical perspective]. In: Bunar, N. (ed) Nyanlända och lärande - mottagande och inkludering. [Newly arrived and learning Reception and inclusion]. Stockholm: Natur och kultur.

Borevi, K. (2002). Välfärdsstaten i det mångkulturella samhället. [The welfare state in the multicultural society]. Uppsala: University of Uppsala.

Bourdieu, P. (1990). The Logic of Practice. Stanford: Stanford University Press.

Bunar, N. (2010). Nyanlända och lärande. En forskningsöversikt om nyanlända elever i den svenska skolan [The Learning of Newly Arrived. An Overview of Research on Newly Arrived Students in Swedish Schools]. Stockholm: Vetenskapsrådet.

Cummings, J. (1991). Negotiating Identities: Education for Empowerment in a Diverse Society. Ontario, CA: Californian Association for Bilingual Education.

Cummings, J. (2000). Language, Power, and Pedagogy. Bilingual Children in the Crossfire. Cleveland, $\mathrm{OH}$ : Multilingual Matters.

Diedrich, A. \& Styhre, A. (2013). Constructing the employable immigrant: The uses of validation practices in Sweden, Ephemera, theory and politics in organization, 13(4), 759-783.

Ds 2013:6. Utbildning för nyanlända elever. [Education for newly arrived students]. Stockholm: Ministry of Education.

Glaser, B.G., \& Strauss, A. (1967). The discovery of grounded theory: Strategies for qualitative research. Chicago, IL: Aldine.

Graneheim, U.H. \& Lundman, B. (2003). Qualitative content analysis in nursing research: concepts, procedures and measures to achieve trustworthiness, Nurse Education Today, 24(2), 105112. DOI: $10.1016 /$ j.nedt.2003.10.001.

Gruber, S. (2007). Skolan gör skillnad: Etnicitet och institutionell praktik. [When school makes a difference - ethnicity and institutional practice]. Linköping: University of Linköping.

Hertzberg, F. (2015). Double gestures of inclusion and exclusion. Notions of learning outcomes, autonomy, and informed choices in Swedish educational and vocational guidance, International Journal of Qualitative Studies in Education, 28(10), 1203-1228. DOI: http://dx.doi.org/10.1080/09518398.2014.974723. 
Hertzberg, F. \& Sundelin, Å. (2013). Counselling between recognition, justice and difference: the significance of power asymmetries, communicative projects and unintended consequences in career counselling of immigrants in Sweden. International Journal of Educational and Vocational Guidance, 14(1), 89-102. DOI: 10.1007/s10775-013-9261-z.

Honneth, A. (1997). The Struggle for Recognition. The Moral Grammar of Social Conflicts. Cambridge, MA: MIT Press.

Kaya, A. (2016). Att undervisa nyanlända. Metoder, reflektioner och erfarenheter. [Teaching Newly Arrived. Methods, Reflections and Experiences.] Stockholm: Natur och kultur.

Launikari M. \& Puukari S. (eds.) (2005). Multicultural Guidance and Counselling. Theoretical Foundations and Best Practices in Europe. Jyväskylä: CIMO.

LeCompte, M.D, \& Goetz, J.R. (1982). Problems of Reliability and Validity in Ethnographical Research, Review of Educational Research, 52(1), 31-60. DOI: 10.3102\%2F00346543052001031

Leong, F.T.L. \& Pearce, M. (2014). Indigenous Models of Career Development and Vocational Psychology. In: G. Arulmani, A.J. Bakshi, F.T.L. Leong \& A.G. Watts (Eds) Handbook of Career Development. International Perspectives. New York, NY: Springer.

Ljungberg, C. (2005). Den svenska skolan och det mångkulturella - en paradox? [The Swedish School and the Multicultural - a Paradox?] Malmö: Malmö University College.

Lovén, A. (2003). The Paradigm Shift - Rhetoric or Reality? International Journal for Educational and Vocational Guidance, 3(2), 123-135. DOI: 10.1023/A:1024708123698

Lundahl, L. \& Nilsson, G. (2009). Architects of their own future? Swedish career guidance policies. British Journal of Guidance and Counselling, 37(1), 27-38. DOI: $\underline{10.1080 / 03069880802535895}$.

McQueen, P. (2017). Social and Political Recognition, The Internet Encyclopedia of Philosophy. http://www.iep.utm.edu/, 2017-02-28.

Migrationsverket (2017). Asylsökande till Sverige under 2000-2016. [Asylum-seekers in Sweden 20002016].

http://www.migrationsverket.se/download/18.585fa5be158ee6bf362fd2/1484924988834/A syls\%C3\%B6kande+till+Sverige+2000-2016.pdf. 2017-01-23.

Nilsson, J. \& Axelsson, M. (2013). “Welcome to Sweden": Newly Arrived Students' Experiences of Pedagogical and Social Provision in Introductory and Regular Classes. International Electronic Journal of Elementary Education, 6(1), 137-164.

Nilsson, J. \& Bunar, N. (2016). Educational Responses to Newly Arrived Students in Sweden: Understanding the Structure and Influence of Post-Migration Ecology. Scandinavian Journal of Education Research, 60(4), 399-416. DOI: 10.1080/00313831.2015.1024160.

Palmer, S. \& Laungani, P. (1999). Counselling in a Multicultural Society. London: Sage.

Parsons, F. (1909). Choosing a vocation. Boston, MA: Houghton Mifflin.

Parszyk, I.M. (1999). En skola för andra: Minoritetselevers upplevelse av arbetets och livsvillkor i grundskolan. [A School for Others. The Experience of Minority Students of Work and Living Conditions] Stockholm: HLS. 
Peavy, V. (1996). Constructivist career counselling and assessment. Guidance and Counselling, 11(3), 8-14.

Ponterotto, J.G., Casas, J.M., Suzuki, L.A. \& Alexander, C.M. (eds.) (2001). Handbook of Multicultural Counselling. Thousand Oaks, CA: Sage.

Resh, N. \& Erhard, R. (2002). "Pushing up" or "cooling-out"? Israeli counsellors' guidance on track placement. Interchange, 33(4), 325-349. DOI: 10.1023/A:1021537720071.

Ricoeur, P. (1981). Hermeneutics and the Human Sciences: Essays on Language, Action and Interpretation. Cambridge: Cambridge University Press.

Rogers, C. (1951). Client-centered therapy. Boston, MA: Houghton Mifflin.

Runfors, A. (2003). Mångfald, motsägelser och marginaliseringar: En studie om hur invandrarskap formas i skolan. [Diversity, contradictions and marginalization: A study in the construction of migrants at schools]. Stockholm: Prisma.

Savickas, M. (1993). Career counselling in the postmodern era. Journal of Cognitive Psychotherapy, 7(3), 205-215.

Sawyer, L. (2006). Att koppla drömmar till verkligheten. SYO-konsulenters syn på etnicitet i övergången från grundskolan till gymnasiet. [Connecting dreams to reality. The views of career counsellors on the significance of ethnicity in the transition from primary to secondary education]. In: Sawyer, L. \& Kamali, M. (Eds.), Utbildningens dilemma. Demokratiska ideal och andrafierande praxis, 187-249. [The dilemma of education. Democratic ideals and othering practices]. SOU 2006:40. Stockholm: Fritzes.

Shan, H. \& Fejes, A. (2015) Skill regime in the context of globalization and migration. Studies in Continuing Education, 37(3), 227-235. DOI: 10.1080/0158037X.2015.1074895.

Skolverket (2008). Allmänna råd för utbildning av nyanlända elever. [General advice for education of newly arrived students]. Stockholm: The Swedish National Agency for Education.

Skolverket (2011). Curriculum for the compulsory school, preschool class and the leisure-time centre. Stockholm: The Swedish National Agency for Education.

Skolverket (2013). Introduktionsprogrammet språkintroduktion. [The Introductory Program Language Introduction.] Stockholm: The Swedish National Agency for Education.

Skolverket (2014). Studie- och yrkesvägledning i undervisningen. [Educational and vocational guidance in education]. Stockholm: The Swedish National Agency for Education.

Spencer, B. (2005). Defining prior learning assessment and recognition. In L. English (Ed.). Encyclopaedia of adult education. Basingstoke: Palgrave Macmillan.

Sue, D.W. \& Sue, D. (2001). Counselling the culturally diverse: Theory and practice (6th ed.). New York, NY: Wiley.

Sundelin, Å (2015). Att skapa framtid. En analys av interaktionen i studie- och yrkesvägledande samtal med unga i migration. [Shaping a future. An analysis of interaction in career counselling conversations with young migrants]. Stockholm: Stockholm University.

Taylor, C. (1994). Multiculturalism: Examining the politics of recognition. Princeton, NJ: Princeton University Press. 
Vesterberg, V. (2015). Learning to be Swedish: Governing Migrants in Labour-Market Projects, Studies in Continuing Education, 37(3), 302-316. DOI: 10.1080/0158037X.2015.1043987.

Vygotsky, L.S. (1978). Mind and society: The development of higher mental processes. Cambridge, MA: Harvard University Press.

Webb, S (2015). 'It's who you know not what': migrants' encounters with regimes of skills as misrecognition. Studies in Continuing Education, 37(3), 267-285. DOI: $\underline{10.1080 / 0158037 X .2015 .1007938 .}$.

Yakushko, O.; Backhaus, A., Watson. M., Ngaruiya, K. \& Gonzalez, J. (2008). Career Development Concerns of Recent Immigrants and Refugees. Journal of Career Development, 34(4), 362396.

Yogev, A. \& Roditi, H. (1987). School Counsellors as gatekeepers. Guidance in poor versus affluent neighbourhoods. Adolescence, 22(87), 625-639. 